\title{
Exploratory Research on Protective Factors Associated with Youth Offending: The Case of East Gojjam Zone,
}

\section{Ethiopia}

\author{
Sintayehu Tilaye (MSW) \\ Lecturer at Ambo University \\ College of social science and humanities Department of Social Work \\ E-mail: sintayehu.tilaye@ambou.edu.et; sintishethio@gmail.com
}

Received: August 10, 2017 Accepted: October 8, 2017 Published: October 10, 2017

doi:10.5296/ijsw.v4i2.11967ＵRL: http://doi.org/10.5296/ijsw.v4i2.11967

\begin{abstract}
The youths have consistently been hypothesized to be disproportionately responsible for crime and are more vulnerable to violence than any other age group which is costing the community billions of dollars per year, creates a sense of fear and lowers the quality of life for many people. In the first section of this paper, risk factors of youth offending were studied. This research deals on protective factors of youth offending in East Gojjam Zone which is located in Amhara Regional state of Ethiopia. Led by constructionist approach, this research used qualitative exploratory case study strategy. In-depth interview with youth offenders and non-offenders, key informant interview with officials mainly from police and correctional center were the central data collection technique. In addition, document review was also used to get any supportive data from various offices and researches. Generally sixteen youth offenders and thirteen key informants, a total of twenty eight participants were participated. None probability sampling method of purposive sampling technique was employed to select the research participants. Age, gender, and social setting of rural vs. urban were considered to select research participants and get comprehensive information. The finding of the study shows that economic improvement including employment opportunities, increased level of awareness, affiliation to law-abiding youths, consistent parental supervision, family stability and free familial relationship, proper family socialization, adequate income of the family, youth's steady enrollment to school, and provision of extra circular activities are protective factors of youth offending. In addition, separated rehabilitation center for adolescent and adult, economic development of the community, limiting the accessibility of alcohol and guns, strong culture against crime, strengthening traditional conflict resolution mechanism, expansion of youth centers with possible services, well equipped lawyers and police officials, strong
\end{abstract}


organized community policing strategy, and improved rehabilitation service are also another opportunities found that reduce the risk factor of youth offending behavior. The finding shows that those multi-level personal, peer, familial, school, cultural, and community level opportunistic factors are not exclusive rather interdependent. Therefore, in order to reduce youths' involvement in offending behavior, stockholders could work collaboratively.

Keywords: Youth, Offending, Offender, Youth offending, Youth offender, Protective factor

\section{Introduction}

\subsection{Background of the Research}

Curtain (2003) defined that youthful age is the age of transition from adolescence to adulthood, dependence to independence, and from being recipients of society's services to becoming contributors. However, Moon, Patton and Rao (2011) noted that susceptibility to adversity is heightened during this period of accelerated maturation and social transition, in the human life cycle. Of several problem behaviors observed at this age, youth offending is becoming the most pressing issue throughout the world. The youths have consistently been hypothesized to be disproportionately responsible for crime and are more vulnerable to violence than any other age group (Farrington, 2003). Crime committed by youth is costing the community billions of dollars per year (YJB, 2002), creates a sense of fear and lowers the quality of life for many people (Geason \& Wilson, 1988). For instance, in Africa, violence-related injuries are one of the top three killers of young males next to HIV and AIDS and TB (AU, 2011). All over the communities whether affluent or poor, urban, suburban, or rural, all are affected by the effects of youth offending (McClinton, 2004).

Furthermore, as the age of transition, researchers indicated that the deficits, deprivations and other risks experienced during youth have debilitating emotional, political, economic and social consequences for those concerned, and their families and communities. When young people fail to realize their full potential, this undermines their future capabilities as adults, thereby weakening whole communities and economies. Especially in many low-income countries with exceptionally youthful populations, this results in a substantial loss of national developmental momentum (UNDP, 2014).

Physical and mental health problem, emotional and/or aggressive behavior, economic problem including unemployment, and substance abuse (mainly alcohol and chat), affiliation to youths with deviant behavior, poor parental supervision, crime history of the family, poor socialization, lack of awareness, increasing trends of street youths, incidence of crime, cultural opportunities for crime like the culture of revenge, availability and unlimited accessibility of alcohol, and availability of guns are the main risk factors of youth offending (Sintayehu, 2015).

Hence, this research aims to examine possible mechanism or protective factor which possibly curbs the risk factors in order to reduce youth offending.

Problem Statement

Across different nations, Ozarow (2011), Mortimer (2010); Case and Haines (2007); Farrington (1986); and Sampson and Laub (1992) studied that incidence of youth offending high and concluded that disproportionally youth are found to be vulnerable to violence than any other age group. Accordingly, researches are conducted about risk factors contributed for 
youth offending. In Ethiopia, though the official statistics of youth crime is more prevalent, less emphasis is given to deal with mechanisms of reducing youth offending. As a result, this research will fill knowledge gap and is going to examine most prevailing protective factors of youth offending in East Gojjam Zone of Amhara Regional state of Ethiopia.

\subsection{Objectives of the Study}

The main objective of this research is: to explore protective factors reducing youths' involvement in criminal offenses and control the risk factors of youth offending.

\subsection{Theoretical Framework}

For this research Urie Bronfenbrenner's ecological system theory is used. He defined ecological systems theory as follows; it is an approach to study of human development that consists of the scientific study of the progressive, mutual accommodation, throughout the life course, between an active, growing human being, and the changing properties of the immediate settings in which the developing person lives, as this process is affected by the relations between these settings, and by the larger contexts in which the settings are embedded (Bronfenbrenner, 1989).

He later strongly suggested that in order to understand human development; one must consider the entire ecological system in which growth occurs (Bronfenbrenner, 1994, pp. 37-38). Hence, EST is a paradigm which encompasses multi-disciplinary theories across multiple levels of functioning (e.g., individual, peer, family, school, community); views the communities from a broad, interdisciplinary perspective that encompasses bio-ecological and macro-economic concerns, but gives greater attention to the social, psychological, institutional, and cultural contexts of people-environment relations (Stokols, Lejano, \& Hipp, 2013; Bronfenbrenner's, 1979).

Ecological system theory looks at an individual's development and behavior within the system of the interactions between an individual, immediate environment (family, school, and peers) and larger social environment (community, society, culture), as well as interactions among different levels of the environment (Bronfenbrenner, 1977; Moon, Patton, \& Rao, 2011, pp. 3-4; Bronfenbrenner, 1979), which is the main concern of this research, observing youths' problem behavior such as offending in context.

According to the ecological system theory the participants in environments include individuals, small groups, organizations, and larger communities and populations (Stokols et al., 2013). All existing elements within an ecosystem play an equal role in maintaining balance of the whole (Hepworth et al., 2010).

Satisfaction of human need or mastery of developmental tasks requires adequate resources in the environment and positive transactions between people and their environments. Any gaps in the environmental resources, limitations of individuals who need or utilize these resources, or dysfunctional transactions between individuals and environmental systems threaten to block the fulfillment of human needs and lead to stress or impaired functioning (Hepworth et al., 2010).

Problem behavior is influenced by ongoing qualities of an individual's social environment and the interaction between the social environment and that individual's personal characteristics (Bronfenbrenner, 1979, 1988). According to ecological system theory human 


\section{$\triangle$ Macrothink}

problems are derived from the complex interplay of psychological, social, economic, political and physical forces (Pardeck, 2015). Because, it is based on the notion that human development is influenced by the different types of environmental systems (Kemp, 2015).

Social ecological analyses incorporate multiple levels of analysis and diverse methodologies for assessing the resilience and healthfulness of settings and the well-being of individuals and groups (McLeroy, Bibeau, Steckler, \& Glanz, 1988; Winch, 2012). Bronfenbrenner (1994) stated that "the ecological environment is conceived as a set of nested structures, each inside the other. Moving from the innermost level to the outside" (p. 39). Bronfenbrenner (1979; 1994; 1989) suggested five levels of ecological components as a useful framework in understanding how individual or family processes are influenced by hierarchical environmental systems in which they function. These are;

Microsystems Is an individual's immediate environment contains the structures with which the individual has direct contact, eg., family, school, peer group, church..... At this level relationships have impact in two directions called bi-directional influences.

Mesosystems Is the relationship between microsystems, e.g., the relations between home and school, school and workplace, etc.

Exosystems Is the relations between a Microsystem and a system in which the individual is not directly involved, e.g., for a child, the rela-tion between the home and the parent's workplace; for a parent, the relation between the school and the neighborhood peer group.

Macrosystems Consists of the overarching pattern like culture or subculture, belief systems etc.

Chronosystems Is the way in which environmental effects develop over time, e.g. changes over the life course in family structure like divorce affect the individual's growth and development, socioeconomic status, employment, place of residence, or the degree of hecticness and ability in everyday life (Bronfenbrenner, 1994, pp. 39-41).

According to Bronfenbrenner, all these five systems have rules, norms, and at the same time roles that shape development of human beings (NACCE, 2015). Some recent social work models added the physical environment as a separate dimension because it is assumed that failure to include the physical environment has most notably hampered social work's ability to respond to persons with disabilities (Hutchison, 1999).

EST based analysis places an individual at the center of micro-, meso-, exo-, macro-, and chrono-system levels. Within each of these ecological settings, individuals are exposed to risk factors that increase the likelihood of negative outcomes and protective factors that decrease such outcomes. This includes: individual-level psychological factors, interactions with peers, family and teachers, community structural characteristics, and historical factors (Shaffer, 2014). EST recommends any efforts to promote organizational or community resilience should be based on an understanding of the dynamic reciprocal transactions that occur among diverse environmental and personal factors, rather than on analyses that focus more narrowly on specific environmental, biological, or behavioral causal factors (Stokols et al., 2013).

The other key assumption of EST derived from systems theory is interdependence, to understand the interrelations among people and their surroundings (Bronfenbrenner, 1994). EST based analyses suggests that the resilience of particular settings and the well-being of 
their participants are jointly influenced by multiple facets of the physical environment and the social environment (Stokols et al., 2013). McLeroy et al. (1988) called this 'reciprocal causation' to justify how an individual behavior shapes, and is shaped by the social environment. Therefore, efforts to understand and enhance the resilience of particular human-environment systems must take into account the interdependencies that exist among immediate and more distant environments (Stokols et al., 2013; McLeroy et al., 1988).

\subsection{Concluding Points on Ecological Theory}

This research is designed to examine protective factors of youth offending behavior. Professionally, multidimensional or integrative approach, focusing on the bio-psycho-social aspects of the person has been the most enduring culture of social workers for investigation and intervention. To this ecological systems theory is a holistic and broad scope theory which enables to appreciate and understand the existence of multiple truths and multiple ways of knowing in context, and enable to identify factors from different aspects/ levels and get holistic understanding of human behavior. However, other theories such as rational choice theory, differential association theory, social support theory, and labeling theory had relied only to justify crime from a particular aspect.

\section{Reviewed Literatures}

\subsection{Youth Offending}

Sociologically, Curtain (2003) stated the sociological definition of youth as "a life stage comprising a series of transitions from adolescence to adulthood, from dependence to independence, and from being recipients of society's services to becoming contributors to national, economic, political and cultural life" (p. 74). Whereas, interims of age, considering curtain's sociological definition, the researcher viewed youthful age as a period of transition, and aimed to identify factors affecting their successful transition to the adulthood period. Therefore, this study utilized UN and World Bank's definition of youth whose age between $14-24$

Broadly, Bohm and Haley (2005) advocated crime in two ways: legally and socially. The legal definition shows "an intentional violation of the criminal low or penal code, committed without defense or excuse and penalize by the state" (pp. 24-25). EFDRE Criminal Code, under Proclamation No.414/2004, Article 23 defined crime as follows: "(1) a crime is an act which is prohibited and made punishable by law. In this code, an act consists of the commission of what is prohibited or the omission of what is prescribed by law...." The second and broader definition is social definition, which includes "behavior that violates the norms of the society/anti-social behavior" (Bohm \& Haley, 2005, pp. 24-25). In response of the definitions of crime Wolfgang, Savitz and Johnston (1970) argued that crime is a legal issue (pp. 15-16), which is also true for this research because the legal definition only is used. Conceptually offending and crime has been used interchangeably for similar meaning but offending is found to be well positive. Though there is age variation, generally criminological researchers identified three groups of offenders: juvenile, youth and adult offenders. Wolfgang, Savitz and Johnston, (1970) stated that violation of criminal laws and ordinances are generally considered delinquency when committed by a juvenile (pp. 23-25). However, youth and adult offenders have almost the same legal prescription; specifically, in Ethiopia 
offenders below 18 years have some privileges (e.g. no death penalty). Consequently, in these research youth offending can be defined as violation of criminal laws and ordinances committed by youth and therefore youth offenders are young person who has been convicted for a criminal offense.

About 10.2 million pre-trial detainees and sentenced prisoners in the world (Walmsley, 2013), it is found that young populations are over involved, for example, in New Zealand, young people (17 years or younger) account for $22 \%$ of the total recorded crime (Becroft, 2003); Statistics in USA released in 2006 revealed that just over a fifth (22\%) of young people aged between 10 and 25 reported that they had committed at least one of the 20 core offences in the previous 12 months (Ozarow, 2011, p. 10). Researchers used age-crime curve to describe a characteristic peak found in aggregate crime data when it is plotted against age. Thus, proportion of the population that is involved in offending behavior (in prevalence and frequency) tend to be highest between the age of 15 and 18 (The peaking age), followed by a steep decline to about the mid-20s and a steadier decline thereafter (Farrington, 1986; Mcvie, 2009, pp. 39-40). This general pattern tends to be repeated for both males and females; but, participation in offending is almost always greater amongst male population (Mcvie, 2009).

Crime whether it is committed by young or adult population, it has been identified as serious social problems virtually in every society. Instead of growing to be productive citizens, criminals impose significant costs on society in terms of social resources, and cause non-monetary pain to their victims (Xian Guan, 2009). Besides causing disability, violence-related injuries are one of the top three killers of young males in Africa - after HIV and AIDS and TB (African Union, 2011, p. 46). Crime and the fear of crime lower the quality of life for many people and is also already costing the community thousands of millions of dollars per year in insurance company payouts, police courts and correctional costs, and the replacement of buildings and facilities caused by crimes (Geason, \& Wilson, 1988, p.4).

Researches indicated that throughout the nation, communities whether affluent or poor, urban, suburban, or rural are all affected by the devastating effects of youth violence. Both the $\mathrm{Vitim} / \mathrm{s}$ and the offenders would be affected. Moreover, the consequences would be also extended to society. Young people and their families, friends, teachers, neighbors, and communities suffer. They experience depression, pain, rejection, injury, and even death. Family members experience conflict, sadness, and anxiety (Center on Early Adolescence, 2008).

Matsuda (2009) particularly investigated the impact of incarceration on young offenders and found that the unique experience in prison may influence the normal development of young offenders and hinder normal desistance from crime (Center on Early Adolescence, 2008). Evidence shows that those young people who offend early are more likely to go on to be adult offenders (AIC, 2007).

Miller (2004), an economist calculated the costs of problem behaviors such as: crime, substance abuse, smoking, dropping out of high school, suicide attempts and other more which occurred in 1998 by all youth in USA. These costs included medical treatment, use of government and community resources, loss of work, and decline in quality of life. Accordingly, he estimated the total cost of problem behaviors that occurred in 1998 was about \$435.3 billion (Miller, 2004 cited in Center on Early Adolescence, 2008)). Since family, 
school, peer, and neighborhood risk factors interrelated and contribute to all of the problems, preventing one problem could help to prevent other problems as well. He estimated that if the problems of adolescents with multiple problem behaviors are addressed, it could be possible to save as much as $\$ 340$ billion or about $80 \%$ of the total costs, he estimated, to society of all problem behaviors.

Physical and mental health problem, emotional and/or aggressive behavior, economic problem including unemployment, and substance abuse (mainly alcohol and chat), affiliation to youths with deviant behavior, poor parental supervision, crime history of the family, poor socialization, lack of awareness, increasing trends of street youths, incidence of crime, cultural opportunities for crime like the culture of revenge, availability and unlimited accessibility of alcohol, and availability of guns are the main risk factors of youth offending (Sintayehu, 2015)

Researchers also studied about possible solutions what they call it Protective factors of youth offending. To begin with the definition, protective factors are the specific characteristics that promote resiliency (Rutter, 1987; Stouthamer-Loeber et al., 1993); and allow young people to become more resistant of developing offending behavior despite exposure to numerous risk factors (Vien, 2009; Pollard, Hawkins, \& Arthur, 1999). Protective factors provide opportunities for growth, strengthening coping capacities of youths, foster competence and promote successful development by neutralizing the effects of such negative risk factors (Piko, et al., 2005; Davies, 2011; Pollard et al., 1999; \& Vien, 2009; Hawkins et al., 2002). Thus, when protective factors are absent or at their weakest, the negative impact of risk on problem behavior is clearly present (Piko et al., 2005, p. 96). The detail has been made below;

Individual and peer protective factors: High self-esteem, constructive use of leisure time, individual personal behavior (Dekovic, 1999, p. 667), female gender, a resilient temperament, a sense of self-efficacy, and high intelligence (YJB, 2005, p. 128) are some of protective factors of youth offending. Arizona Criminal Justice Commission (2014) has found four individual characteristics as protective factors. Gender -given equal exposure to risks, girls are less likely to develop health and behavior problems in adolescence than are boys; a resilient temperament-young people who have the ability to quickly adjust to or recover from misfortune or changes are at reduced risk; a positive social orientation- young people who are good natured, enjoy social interactions, and elicit positive attention from others are at reduced risk; and intelligence- which is found to be the factor in delinquency rates and school drop-out rates (pp. 20-21). Moreover, religious individual who regularly attend religious services; and belief in the moral order or a person that has a strong belief of what is "right" or "wrong" he or she is less likely to engage in problem behavior (Arizona Criminal Justice Commission, 2004; Fox, 2008).

Bonding/Interaction with pro-social Peers: strengthening youths' bond with positive, pro-social family members, teachers, other significant adults, and/or pro-social friends is found to be one of the most effective ways to reduce the risk. Individuals who are bonded to others who hold healthy beliefs are less likely to do things that threaten that bond, such as use drugs, commit crimes, or drop out of school (Arizona Criminal Justice Commission, 2014, p. 21; Fox, 2008, 38; Stouthamer-Loeber et al., 1993). Young people that engage in positive 
interactions with other who have clear and positive behavior and those who have well social skills will not give in to negative peer pressure as easily (Fox, 2008, p. 37).

Good parental supervision, family stability, parents having clear standards against criminal activity (Arizona Criminal Justice Commission, 2014; Dekovic, 1999); and parent's leaders who lead by example and hold clearly stated expectations regarding young people's behavior are helping to protect against crime. Opportunities for involvement, social and reasoning skills, and recognition and due praise also act as crucial protective factors (YJB, 2005, p. 128). Besides, a longitudinal research made by Arizona Criminal Justice Commission in 2012 and 2014 identified family attachment, family's pro-social involvement, parental monitoring, talking about problems with parents were the main protective factors.

School related protective factors: Strong bonding, when students have healthy relationships with their teachers, when they feel as if they are able to play an active role in their classes and in their school, and when they receive encouragement and support they are more bonded to their school and their commitment to school is less likely to falter. In addition, the negative effects of risk factors can be reduced when schools teach young people healthy beliefs and set clear standards for their behavior (Arizona Criminal Justice Commission, 2012, p. 21). Talking about problems with teachers, participation in school clubs are also other factors to influence youth offending behavior positively (Piko, Fitzpatrick, \& Wright, 2005).

Moreover, School opportunities and rewards for pro-social involvement referring when a young person is presented with opportunities to be involved in positive interactions and activities at school, and when a youth is rewarded or given praise for the work or participation in school, he or she is less likely to use substances or engage in problem behavior (Arizona Criminal Justice Commission, 2004, 2012, p. 17; Fox, 2008, p. 32).

Neighborhood and community protective factors: Dekovic (1999); and YJB (2005) studied that community and neighborhood conducivenesses, and the community's healthy standards and clearly stated expectations regarding young people's behavior are protective factors of youth offending behavior. Likewise, Delgado (2006) forwarded that changing the undeserving attitudes of the adults towards youth, identification of local resources and developing community goodwill to create a favorable condition for youth to participate in the community are possibly mentioned as protective factors (Abraham, 2010). In addition, Arizona Criminal Justice Commission (2014) and Fox (2008) found that when there are opportunities in a community for a youth to engage in positive interaction, and if they receive rewards for positive involvement from the community, he or she is more likely to bond with the community and thus less likely to engage in problem behavior.

Traditional conflict resolution mechanism: Endalew Lagalme (2013) studied the roles of customary dispute resolution mechanisms in Ethiopia over the legal aspects and forwarded that it is playing important role in resolving crimes of any kind and maintaining peace and stability in the community. The customary dispute resolution mechanisms are run by elders; involve reconciliation of the conflicting parties and their respective families using different customary rituals where needed; emphasize the restitution of victims and reintegration of offenders; and aim at restoring the previous peaceful relationship within the community as well as maintaining their future peaceful relationships by avoiding the culturally accepted practices of revenge. 


\section{Research Method}

\subsection{Research Design}

Exploratory research is chosen to generate new insight regarding youth offending. Known researcher like Neuman (2007); Kreuger and Newman (2006); Crow and Semmens (2006) discussed that exploratory research is best to be used when we need to explore a new topic or issue to learn about it and if the issue is new or researchers had written little on it. As a result, the goal of this research is to explore risk and protective factors of youth offending. This research was led by qualitative (constructivist) approach which basically is presumed that reality is subjective. The researcher assumed that the research participants have unique and contextual idea about the issue. According to Crow and Semmens (2006), constructivist approach is focused on studying a phenomenon as it occurs in its natural state. The focus for the research is on extracting the meaning of action. Up on this qualitative type of inquiry is appropriate to fully understand the offenders' explanations of crime, takes into account the complex and multivariate nature of individuals and social influences and supplement statistical models and conclusions with experiential data in studying the real world of offenders and crime (Pogrebin, 2004a; Romanoff, 2012). Moreover, qualitative research is culturally specific and produces contextually rich data (Mack, et al., 2005). Of qualitative research strategies, exploratory case study strategy is used based on its scientific merits. Creswell (2003) stated that strategies of inquiry are used to provide specific direction for procedures in a research design. As mentioned above, the aim of the research is to explore and provide new insight over the issue of youth offending. Therefore, based up on the research approach, method and research questions, qualitative exploratory type of case study is chosen. Since the aim of the research is to provide new insight, Stake's instrumenta 1 type of case study is used. According to Stake (1995) in an instrumental type of case study a particular case is studied to provide insight into an issue or to refine a theory, studies often are investigated in depth, and all aspects and activities are detailed, but not simply to elaborate the case. In this research the issue is youth offending with particular emphasis to risk and protective factors.

The rationale to use exploratory case study research strategy was due to the existing discrepancy of scientific inquiry about youth offending. Yin (2004) articulated that exploratory type of case study research is best applied when a research aims to produce a first-hand understanding of people and events and used for the exploratory phase of an investigation to answer "What" questions in developing pertinent hypotheses and propositions for further inquiry which was the foremost concern of this research. Case study is also appropriate to understand complex social phenomena in-depth and to get complete picture of a unique, special or interesting story of the study case/s using variety of data sources (Yin, 1989; Stake, 1994; Baxter \& Jack, 2008; and Neale, Thapa, Boyce, 2006). Thus, the researcher used all the benefits to explore new, in-depth, holistic and contextual information from multi sources of youth offender/ing.

\subsection{Data Collection Techniques}

The researcher used interview (to gather primary data) and document review (to collect secondary and supportive documents) as the main data collection techniques. To show scientific grounds, Yin (2004) recommended that documentation, records, interviews, 
physical artifacts, direct observations, and participant-observations are the most common sources of evidence in doing case studies. Interview guides was prepared for the youth offenders and key informants, and secondary data collection checklist were used as an instrument of data collection. Colton and Covert (2007) showed that the type of instrument typically based on: the purpose of the study, the research design, resources and time constraints which were also considered very well.

In-depth interview: the researcher used in-depth interview with sixteen interviewees which was entirely conducted by the researcher himself. Colton and Covert (2007) called this 'self-report method,' interviewees are asked to reply information directly to their own detail. Scientifically, Natasha, et al. (2011) supported that in-depth interview is optimal for collecting data on individuals' personal histories, perspectives, and experiences, particularly when sensitive topics are being explored, for example in this case crime.

Key informant interview: Police officials, community dwellers, non offender youths, correctional center officials and female, children and youth affair offices were interviewed to get different insights about the offenders, the offending and the environmental context.

For in-depth as well as key informant interview, guiding questions were prepared but it was more flexible and in the middle of conversation probing questions had been used to encourage them to elaborate their answers, clarify and get more understanding. Maxwell (1996) recommended that the researcher should use "probing" questions to gain additional information about context (in Higgins, 2009).

Document Review: Police crime record and correctional center's annual report were used to augment the information collected from primary sources. Moreover, published and unpublished materials like books, articles, thesis, dissertation, seminars, reports and institutional documents has been used to get better understanding of the methodology, theory and the issue under study. Neuman (2007) mentioned that from existing statistics a researcher locates previously collected information, often in the form of government reports or previously conducted surveys, then reorganizes or combines the information in new ways to address a research question.

\subsection{Sampling Techniques and Procedures}

Study participants and sampling method: Youth offenders whose age between 14-24 were participants of the study. As the case study research, youth offending is the issue/case that this research has explored. The researcher used non-probability sampling method, specifically, purposive sampling technique. This is because the research participants of the youth offenders and key informant interviewees were selected purposely to get pertinent information convenient with topic of the research. Teddlie and Yu (2007) noted that purposive sampling technique refers selecting units based on specific purposes associated with answering a research questions. The characteristics of the research participants, like gender, age and social setting (rural vs. urban) of the offenders were considered to select the research participants to get holistic information. An organization called Laerd Dissertation (2012) named this "maximum variation sampling," also known as heterogeneous sampling. It is stated that maximum variation sampling is one of the types of purposive sampling used to capture a wide range of perspectives and used to gain greater insights into a phenomenon by 
looking at it from all angles.

Based on the saturation of the information and taking the average of different researchers' experience, sixteen youth offenders were interviewed. Mack et al. (2005) provided that purposive sample sizes are often determined on the basis of theoretical saturation. Moreover, 12 key informant interviewees: four Woreda police officers from crime investigation and community policing department; one correctional center officer, two community dwellers, three Woreda and Zonal Female Children and Youth Affaire Officer and two non offender youths were interviewed to support the study participants' idea.

Inclusion Criteria: Age and crime records were the main inclusion criteria to select youth offenders. Only youths whose age between 15 and 24 and who had sentenced for their criminal act were included. Detainee youths were not incorporated in the research because they are no longer criminals unless they are found to be guilty of crime. In addition, to select key informant interviewees, issues like their understanding, experience, and responsibility related to the issue were taken in to consideration.

\subsection{Data Analysis Technique}

The research used thematic analysis technique. Based on the research questions, transcribed data has been reduced in to themes and analyzed accordingly. According to Dawson (2007) thematic analysis is used if the research is inductive; the themes emerge from the data and are not imposed upon it by the researcher. Since the research is exploratory type, though the research participants' (youth offenders) response is considered to develop themes, information gathered from different unit of observation is also analyzed to explain and get full information of the research topic. Baxter and Jack (2008) mentioned that in case study, data from multiple sources are then converged in the analysis process. Each data source is one piece of the "puzzle," with each piece contribute to the researcher's understanding of the whole phenomenon and promote a greater understanding of the case.

\subsection{Ensuring Trustworthiness}

In order to keep the trustworthiness of the research: the researcher was genuinely present realistic information of the interviewee's opinion and their meaning to the problem; keeping scientific procedures of the research process (e.g., the interview was made by the researcher himself); prolonged engagement; validation of the instruments by peer review; and using triangulation method in source of information(primary and secondary), and unit of observation (youth offenders and key informants from different sectors). Crow and Semmens (2006); Hussein (2009) mentioned that triangulation- using the combination of two or more theoretical perspectives and data sources to study the same phenomenon, is one of the validity measures in research.

\section{Findings of the Research}

\subsection{Background of the Study Area}

This research is conducted in East Gojjam Zone particularly in Debre Marko's Correctional center which is found at Debre Marko's town. East Gojjam Zone, one of the 11 zones of Amhara regional stat in Ethiopia and contains 17 Woredas and 4 city administrations (East Gojjam Zone tourism directive, 2014). The total population of east Gojjam Zone is about 2, 496,325. Of this population, youth whose age between 15 and 24 were 569, 374, constituting 
$23.89 \%$ of the total population. Youths who live in rural area accounts $78.1 \%$ of the total youth population (East Gojjam Zone Economic development directive, 2015). Debre Marko's is the capital city of East Gojjam zone which is found approximately $300 \mathrm{~km}$ north-west of Addis Ababa and $267 \mathrm{~km}$ south-west of Bahir Dar, capital of the Amhara regional state. It was established by Dejazmach Tedila Gualu in 1845 E.C by the name 'Menkorer.' Following the establishment of St. Marko's church, the name has been changed in to Debre Marko's after two years of the reign of king Teklehaimanot in 1872 E.C. (Debre Marko's communication office, 2017).

There are three correctional centers found in East Gojja zone: Debre Markos, Bichena and Motta. Of which Debre Marko's correctional center was the focus of the research which constitute offenders from nine Woredas. Informant from a religious leader and religious bulletin prepared for the commencement of the St. Marko's Church indicated that the prison was reestablished by Ras Hilu Belew after 1934 E.C. (St. Marko's church commencement bulletin, 2012). Legends showed that since the prison was inconvenient and many offenders died there, informally it was called "dem melash'in Amharic " "to show as the prison by itself revenge the offender. Later on the current correctional center has been relocated to the outer edge of the town by the year 1992 E.C. At the time of data collection there were 1591 prisoners and detainees with 9 tributary adjacent Woredas (Debre Markos correctional center monthly report, 2015).

\subsection{Protective Factors for Youth Offending}

Economic empowerment including Employment opportunities: interviewees such as Getachew, Temesgen, Tilahun, Getinet, Mengistu, and informants like Sajin Zewdu, Zewdu, Addissu, Esubalew and inspector Aynadis mentioned that employment opportunities and other economic engagement of youth could be the way to let out them from their criminal behavior. For example, interviewee Getinet said that his unplanned migration to urban area was ended with being a street youth which ultimately exposed him for lack of food to eat. He narrated that;

... After becoming a street youth, I didn't have any alternative than being a robbery because I couldn't maintain otherwise. .... My basic needs plus involuntarily adopted addictions of drugs in the street heighten my engagement in criminal activities...... as usual, in that day we asked the owner of Baflo Hotel to give us crumb (he called in Amharic 'ooffa') but they didn't. As a result we took material secretly from the hotel for which I accused of theft.

They focused that the family has to be the responsible in establishing youths' economically; initiating youth's commitment to work through modeling and providing conducive environment; and altering the working habits of the youths.

Female, children and youth affaire office, police and other informants listed government's small-scale and micro enterprises programs, agricultural opportunities (livestock and land), irrigation and available training centers like TVT as an existing opportunities for youths that can be used as a means for their economic empowerment. Though there are other more driving factors associated with youth's mass migration and increment of street youths, interviewees forwarded that empowering youth's economic capacity can reduce urban ward migration and street youth. Together with creating job opportunities in both rural and urban 
areas, police officers intended institutional based establishment center to treat street youths through providing shelter, and other basic foods with some sort of training to reduce the effect of street youths and let them to be productive citizen.

Increased level of Awareness and complains to the Normative/positive behavior: confirming lack of awareness as a main causal factor, interviewees like Solomon, Abebech and Demelash, and Sajjin Aynadis suggested that youth's increased level awareness can be an opportunity to reduce youth's engagement in offending activities. They said it enables them to rationalize the offense not to commit. Mitiku who was accused for homicide at the age of 16 regretted the event at the time as follows;

..... We were celebrating epiphany together with my older brother. While we were playing hockey (traditionally called "gena"), when my brother kicked the hockey ball by coincidence the hockey ball hit one of our opposite team members and he was blooded. In return they kicked my brother. ... Since I was worried about my brother, I didn't recognize the consequences of death. I arrived and immediately bludgeoned at his head. He fall down and blooded. The issue was silly and reversible however, he eventually died.

Teferi, Selomon and Kasahun, Zerihun, Selamnesh, Shiferaw, Ato Beyene, inspector Aynadis and Sajin Zewdu stated that youths' positive behavior of non-violent, drug free, tolerant and being obedient who are pro family and community norm are protective factors. As mentioned by the police, especially using alcohol appropriately if not possible to cut, can reduce youths offending.

Affiliation to law-abiding youths: research participants, for example, Teferi, bearing in mind how he was influenced by his friends; he said being selective before getting intimate relationship can be an opportunities to reduce offending. He further elaborated that the youth may learn positive behaviors if they become friend with whom who have good behavior. Informant from police officer also strongly supported the advantage of affiliation to law abiding youths.

Youth's self-assertiveness: FCYAO and police officials intensively answered that youth's self-assertiveness, being confident and decision maker is an opportunity to prevent youth offending because they replied that it enables them not to be manipulated by their friends regarding any type of offense rather it could help them to be rational of their activities.

Consistent parental supervision: interviewees mentioned that both strict control as well as extreme freedom of the family for their children is a risk factor for youth offending behavior. Getinet and Temesgen for example, noted that rather than strict or negligent parenting style, regular supervision of the parent can be a solution to daily and oversee youths' unusual behaviors. Temesgen said that "consistent treatment from the family can keep youths to be out of trouble." He mainly stressed that at the age of adolescent at which youths have a sense of standoff, family's supervision is essential to decrease the problem.

Free communication between the parent and the child: most of the interviewees forwarded that free communication between the children and the parent enables the parents to understand youths' behavior and provide the opportunity to control, advice and treat the youths accordingly. Ato Beyene, and Ato Molla talked similar to this. Dawit, informant from non-offender youth forwarded that free communicate between the parent and youths facilitate 
the youth to speak it out their interest and become an opportunity to know what the youths really need. This allows the parent to look around the situation and treat the youth in context from time perspective.

Family stability: stable family without conflict and divorce are stated as the opportunities to protect youths. Interviewees noted that the presence of both parents is significant for their stability. When unintentional death or divorce happens, interviewees pointed the issue of establishing youth to put aside them from discomfort, disintegration and psychological stress especially absent parent youths would be a concern.

Kassahun talked that the turning point of the offense was his parent's divorce. He said after divorce, his parent argued over him to decide with whom he should live. He elaborated that;

...... my parent got divorce. .... When they get conflict over me to decide with whom I should live, in the process I have quitted my education. After that my life has got problem, I started to make use of cigarette and chat; and had imprisoned seven months for the offense of arson. Again I was also accused of theft.

Proper family socialization: informants forwarded that family's appropriate socialization of youth starting from early child hood period to be law abiding citizen, and develop good personality were predicted opportunities to reduce the vulnerability of youth to their further offending behavior. For example, Shiferaw illustrated that especially his father's socialization style let him to be fighter. He mentioned as follows;

.... Starting from childhood my father always told me that I should not be beaten by any one rather than being always a winner. He was encouraging me to fight with my peers. I was beaten back if I had failed to win out my frien..... Economically, we are rich. When my parent got divorce, my mother gave me heifer, cow, and ox from her part. However, my father gave me weapons: one pistol, two hand bomb, and one kilash with sufficient bullet....

Adequate income of the family: pointing the fact that most of the youth's offense is associated with the economic problems. Getachew, Hiwot, and Temesgen responded that family's economic capacity is a protective factor. Ato Beyene and other interviewees supplemented that family's adequate income can be at least a means to discharge the aforementioned (personal and familial) and other subsequent (school and community) factors. Family's adequate provision of the required needs and wants including basic needs, education, treatments and economically establishing of youth facilitate youths' better community engagement and decrease their offending behavior.

Mengistu responded; "My family's economic situation was uncertain; my mother always wounding me that I was not lucky particularly for the absence of cow for milk. Then I had decided to stop my education and became a cowboy to support my family." He acclaimed his family's economic situation for the happening of the offense because he justified that, "if my family was economically better, I wouldn't have dropped my education and commit the offense."

Youth's steady enrollment to school: Getinet, Temesgen, Mengistu, Selamnesh, Kasshun mentioned this to be a possible solution from two main perspectives. Kasshun talked that youths' enrolment to school reduce the vulnerability of youths to commit offense since they use their time fully for education and get better attention from their family and community. 
On the other hand, police officials and few research participants also related youths' continuous enrollment to enhance their awareness level.

Delivering quality and creative education: Ato Beyene's mentioned that the role of quality education is either to enhance economic situation or advancing awareness level of youth which he assumed reduce youth offending. Ato Beyene further showed that the current unemployment and independent thinking of both educated and uneducated youths sourced from luck of quality education. As a result, he pointed that quality education in every level will be an opportunity to create competent youths to be creative and independent. He elaborated as;

...if quality education is given starting from the lower class, youths do not drop out from school rather they finish their education and be successful in their profession or be creative if they fail to work with their profession rather than engaging in offending activities.

Strong supervision at school: well controlling system of the teacher and the school in general are identified as protective factors, as mentioned by Ato Beyene, to positively force youth's commitment and continuous attendance. In addition considering their educational experiences, Solomon and Teferi pointed out that intentionally or unintentionally the student may miss class, fail to do the required assignment, play gambling, and use drug and substances with their friend. They revealed that if strict measurement is taken timely, they may give attention and improve for the coming day.

Provision of extra circular activities at school: though it is not explicitly mentioned by the research participants, together with supervising and controlling students at school, the provision of extracurricular activities and youth's participation can be an opportunity. Because it helps to develop different supplementary skills, filter out their natural potentials, experience responsibility, and give attention to the norms of the school than being deviant and offender.

Economic development of the community: Solomon and Kassahun, and Police officials intended that solving unemployment and other economic problem of youths in the community will reduce exodus towards urban as well as number of street youth which directly reduce the incidence of crime. Therefore, economic development of the community especially job opportunities are the most repeatedly thought protective factor to reduce youths offending.

Key informants such as Esubalew, Ato Addissu, and inspector Zewdu confirmed that there is an increasing trend of street youths due to exodus of youths to urban. They pointed that most of the offenders are migrants, who come from rural areas. Ato Addissu further stipulated that; Form our investigation; most of the offenders are from rural areas. Initially they come for better job opportunities, some of them may get job but others may not. Those individuals who did not get job become street youths and/or engage in different criminal activities.

Strong culture against crime: cultural factor such as blood feud was found to be the most risk factor of crime in the community. Zerihun, Temesgen, Shiferaw's and Mengistu pointed ameliorating cultural opportunities of crime could be the main ending solution. Informants such as police officials and Ato Molla and Ato Beyene added to this. Particularly police officials forwarded that they are planning to use community policing as an additional 
opportunity to increase the awareness level of the society regarding revenge, recurrent conflict due to border conflict and other issues.

Limited accessibility of alcohol and guns: almost more than half of the offenders used alcohol at the time of the crime and of sixteen interviewees, more than five offenders used gun at the time. The fact that the availability and unlimited accessibility of alcohol were contributing factors for the offense; both informants like Ato Beyene and interviewees mentioned that reducing alcohol consumption if not possible to cut. Research participants didn't mention the issue of availability and accessibility of alcohol for all age group. However, they said at least children below 18 ages must be restricted not to access alcohol. Regarding the availability of gun, police officials, Ato Molla, Shiferaw and Zerihin suggested that reducing individual's ownership of gun to only concerned and security personnel will be the solution to reduce youth offending.

For example, Shiferaw regreated and said that the consequence would not have been much serious if he hadn't used hand bomb. He added that; "gun is not like that of stick and other instruments rather it is either to kill or to injure severely." He responded that in his community (Dejen Woreda) almost every individual has gun even those individual who doesn't have ox. Due to this you may not find individuals who hadn't been engaged in homicide either by himself or with his relatives. Other interviewee named Tiruneh said that, getting gun at hand create more confidence and may initiate to commit crime unwisely. This information was also supported by police officials as it causes to youths offending behavior.

Strong traditional conflict resolution mechanism: the availability and strengthen of traditional conflict resolution mechanisms is frequently mentioned solutions of youth offending by interviewees as well as informants. Zerihun and Mengistu explained that strong traditional conflict resolution mechanism reduces further criminality among each other. For example, Zerihun said "as soon as the conflict happens, the two parties should reconcile their problem with appropriate reimbursement because whatever the punishment given to the offender with the legal process, both of them will be disadvantageous." Similarly, Mengistu suggested arbitration using the community's elders to reduce further enmity between the offenders and the victims rather than reporting every silly issue to the police.

On the other hand, inspector Esubalew indicated contrasting idea. He said,

Solving conflict and other offenses using traditional conflict resolution mechanisms needs serious attention. For example, previously the offender and the victim agreed to reconcile their case and the victim received money for compensation. Then the victim immediately bought gun with that money and revenged the offender back.

Inspector Esubalew, however, supported this mechanism to be used for the less serious types of crime which will be good and even effective better than the legal process.

Expansion of Youth centers with possible services: Zonal and Woreda level FCYAO officials stated that even though it is not fully working, youth centers in both rural and urban areas could be another opportunities. Intended services such as, training, information technology centers and entertainment centers encourage youth's creativity rather than being engaged in other addiction and offending behaviors because, informants described that youths need to stay there, participate in different clubs and serve the community in different ways. This 
participation creates positive attitude of the community regarding youths as well.

Strengthening Small scale and micro enterprises: In the above section, youths' economic problem was stated as a risk factor. As a result, FCYAO pointed the existence of such opportunities for youths to address their economic problem and reduce unemployment. However, research participants claimed different hindering issues getting the opportunity of small scale and micro enterprises like limited access of credit. But with its deficiencies, they forwarded that this can be opportunity to reduce unemployment as well as youths' offending behavior.

Well organized Community policing strategy: Sajin Zewdu, talked that community policing strategy is a community based crime prevention method that has been implemented since 2008. They said it is working mainly on awareness creation and get behavioral change of crime. There are four main structures community policing uses to launch awareness: home to home teaching; village level conflict resolving, counseling and arbitration committee; school counseling committee; and kebele counseling committee. Therefore, they suggested that if it is made optimally, this community based crime prevention mechanism can be protective factors to prevent crime.

Well educated lawyers and police officials: to prevent False and/or collective accusation: Informants and interviewees talked that well trained, experienced and honest lawyers as well as police officials are needed to reduce false and/or collective accusation. As far as the researcher used optimum mechanism to get their trust, from 21 selected possible interviewees, five youth offenders had already got the decision but they said that they didn't commit the offense rather they thought that they were imprisoned without adequate evidence and/or together with other offender. In addition, key informants from Debre Marko's correctional center, Mulugeta, counseling officer pointed that research conducted by Amhara regional state level of correctional center forwarded that about $45 \%$ of the prisoners were imprisoned with false evidence. Zerihun responded that;

I did the offense by myself, my brother did nothing, he arrived later than the conflict but they accused him together with me. It is not only my concern rather there are also individuals who are imprisoned in group for a single crime though the offence is committed by an individual.

Likewise Shiferaw added, “...my father was accused and sentenced 20 years of imprisonment together with me. But he didn't even see the event. They accused him because they fear that my father will revenge them back." Temesgen pointed that especially previous offenders are vulnerable for false accusation. On the other hand, some other interviewees observed this as it is weak investigation procedures of the police and the court. Concerning this, Shiferaw claimed that when the victims report the wrong offender, the lawyers, and the police shouldn't investigate the case in detail to get the real offenders. He added;

... For example, while I was outlawed, one of my enemy's family members was killed and injured by unknown individual. But after my submission to the police, they accused me again for the death and injury of those individuals because they do not want me to be released since they assume that I may commit another offense on them. I didn't make that but the court decided on me another 11 years of imprisonment.

Inclusively they talked that the accusation of individuals without adequate evidence is 
common mostly for two reasons. First, if the victim previously had enemy or conflict with someone else, and if any violence or mistreatment happens, she/she reports his enemy to the police without detail investigation. Whereas the second reason is, for a crime, the victim himself or his family accused more than one or even the whole family members of the offender. Shiferaw stated that this is because they assume that if the offender only is imprisoned, they fear that the accused family will take another action. The main argument here is that, either accusing the offenders without detail investigation or accusing more than one criminal for a single crime affect individual's further criminal act. He/she will develop enmity towards the accuser and commit another offense.

Improved rehabilitation service: police officials form the correctional center and the prisoners themselves confirmed that the type of rehabilitation services given in the correctional center could be made to reduce youth's further offending behavior. They argued that it is possible to improve the offending behavior of the youth if youth offenders are rehabilitated well, trained, counseling and coordination is made with other sectors of such as police, small scale and micro enterprise, TVT and FCYAO, and follow up of offenders is made to start their own business and lead their life properly. It is basically aimed to reduce reoffending behavior. For instance, Shiferaw said

,...here, I have been attending my education. Moreover, I took several trainings like computer, wood work, and metal as well. I hope these will help me to work in my community if conditions will be conducive...

Separated rehabilitation center for the adolescent and adult: confirming the existing integrated system of rehabilitation for adult and child offenders, officials from the correctional center pointed that making offenders aged between 15 and 18 separately from adult offenders can be an opportunity to reduce reoffending. They justified that when both adult and children placed at the some institution, children learn various type of crime from adult offenders rather than being rehabilitated. Moreover, officials described that children need especial psychological advice to reduce the impact of the offense for their further life.

\section{Discussion}

This section is devoted to state findings of the study and discussed with existing enquiries. To begin with the first issue, this study has found that increased level of awareness, positive behavior such as non violent behavior, free from substance, compliant to the family and community's norm) and economic development including employment are found to be taken as personal level protective factors. Researchers such as Dekovic (1999); YJB (2005) forwarded that high self-esteem, resilient temperament and high intelligence positively causes youths' offending behavior. In addition, Arizona Criminal Justice Commission (2014) added that being female, and positive social orientation are individual characteristics as protective factors. More uniquely, this research revealed that reducing the use of substance especially alcohol and employment opportunities are the main protective factor to reduce youth offending.

Regarding peer related factors, Fox (2008); Stouthamer-Loeber et al. (1993); Shader (2002); and Piko, Fitzpatrick, Wright (2005) and Arizona Criminal Justice Commission (2014) examined that a person who interacts with peers who have positive behavior and who hold 
healthy beliefs served youths to protect against criminality. Similarly, affiliation to law-abiding youths is central peer related protective factors that are also found from this study. Moreover, this research explored youth's self assertiveness to be another opportunities because, if a youth is self assertive enough, he/she will not be manipulated by the groups/peers behavior.

On the other dimension, Laser and Nicotera (2011) investigated the positive role of adequate care and support from adults for appropriate passage of youth to adulthood. Dekovic (1999) studied good parental supervision and family stability; YJB (2005) examined parent's clearly stated expectations regarding young people's behavior; Arizona Criminal Justice Commission (2014) showed parent's positive attitude towards crime, family attachment, parental monitoring, free communication between the parent and the young people are the crucial family related protective factors.

Likely, consistent parental supervision, open parental relationship, and marital stability are observed in this enquiry. Nevertheless, as far as cultural factors are prevalent in the area, this research especially found that proper family socialization of the youth as protective factor. Because it enables to acculturate youths culturally accepted opportunities of crime like revenge, and get concerned in positive behaviors. Besides, as long as economic problem is the main cause to crime, adequate income of the family is identified to be another protective factor.

In addition, youth's steady enrollment to school, quality education, strong supervision of the school and the teachers, provision of extra circular activities are identified to be protective factors. Fox (2008) examined and pointed the positive role of youth's strong bonding, their healthy relationships with the teachers, and school and other stockholder's encouragement and support; Arizona Criminal Justice Commission (2012) studied how school's teaching of young people to have healthy beliefs and set clear standards for their behavior; and Piko, Fitzpatrick, Wright (2005) also added student's free talk about their problems with teachers and their participating in school clubs, to increase their bonding and commitment to school are identified as the protective factors to reduce youth offending.

More intensively this research explored that youth's steady enrollment to school provide not only enhanced academic achievement and promoting skills and competencies for further career but also temporarily decrease unemployment so that youths can stay at school than engaging in gambling, using alcohol, and other substances. This research also added as provisions of extra curricula activity increase youths' bonding and commitment to their education, enables to search their natural potential, increase their sense of responsiveness and community engagement which create positive relationship between the adult and the youth. Moreover, delivering quality education is also found to be an opportunity.

The other section is about cultural and community related protective factors. Dekovic (1999) dealt on the positive contribution of community and neighborhood conduciveness; Abraham Genet (2010) examined the contribution of positive attitudes of the adults towards youth; Fox (2008); and Arizona Criminal Justice Commission (2004) studied facilitating prosaically involvement of youths through rewarding as the protective factors to reduce youths offending behavior. Furthermore, Endalew Lijalem (2013) intensively examined the role of traditional conflict resolution mechanism to contribute in reducing further hostility and restoring the 
previous peaceful relationship within the community.

Apart from the other, this research established that economic development of the community is found to be the support of all protective factors. Because this research revealed that when unemployment reduced rural urban migration decrease as a result the number of street youths decreases as well so that youth offending will be minimized. Furthermore, in the area, strong culture against crime is also another protective factor to fight for example the culture of blood feud. This research also explored that not only limiting the use of alcohol but limiting the accessibility of alcohol and guns especially for children can reduce youth offending. Besides, this research also indicated the role of strong traditional conflict resolution mechanism to reduce further enmity.

The last focus is about political and administrative protective factors. This research discovered that available partially working youth centers if the intended services are to be given; small scale and micro enterprises in providing job opportunities and reducing unemployment if all inclusive services are given for all rural urban and educated and uneducated youth; well organized and trained security and lawyers to control and investigate crime properly, and avoid injustice in decisions making process; and improved rehabilitation services to better rehabilitate offenders and separated rehabilitation center according to their age especially are possible protective factors to prevent youth offending and reoffending. In addition, community policing strategy is also another protective factor to prevent youth offending behavior.

Theoretically this research has been lead by ecological system theory, basically assumed that any individual's problem like youth offending is derived from the influence of multidimensional environmental factors. Similarly the finding of the research confirmed that youth offending behavior is caused by several factors starting from individual to the community level factors. On the other way, ecological theory assumed that any intervention program to fix human problem like youth offending should be made not only addressing personal issues but also other social and environmental aspects should be assessed as well. To this, the finding of the research also confirmed that multi level of intervention in individuals, peers, family, school and community is needed to resolve youths' offending behavior.

\section{Conclusion}

The finding of the research shows that there are different opportunities or protective factors that can reduce youths' over involvement in criminal activities: the nature of friendship relationships, family situations, schooling, cultural and community circumstances, and political and administrative related factors are identified as the main protective factors that help to reduce the vulnerability. Six basic categories/themes are found that positively influence youth's offending behavior. The outcome of the research shows that these categories are not exclusive rather interdependent. Therefore, the study pointed out that, existing risk factors can be addressed more consistently through the existing opportunities factors in the community.

\subsection{Social Work Implications}

As a profession with the mission of enhancing human well-being, particularly attentive to the needs and empowerment of people who are vulnerable, oppressed, and living in poverty 
(IFSW \& IASSW, 2004) social work is concerned about the issue of at risk youths, offenders. There are numerous internal/biological and external/social risk factors contributed for high rate of youths' involved in criminal activity. Accordingly, this research identified possible solutions that could curb and reduce youths' involvement in offending.

Social work profession promotes social change, problem solving in human relationships and the empowerment and liberation of people to enhance well-being. Social work intervenes at the points where people interact with their environments (IFSW \& IASSW, 2004). Thus, taking this fact in to consideration, this research has significant implication for social work in showing the role of social workers' at which point they can contribute as a researcher, policy advocator, practitioner, or in education.

Social workers can make practice in assessing or identifying the causal and protective factors to address the risk factors using the existing opportunities. As the main assumption of ecological system theory, the research has got six main domains of both the risk and protective factors of youth offending. Social workers can practice their profession in these six levels. At micro level, social workers can do in addressing individual's problem before the offense and their psychological support through counseling after the offense; and working in peer/group level to make out their relationship conscious and develop self assertiveness. From the family contexts, creating harmonious relationship between the family and the youth, and insisting the family to understand youths in age and time context; and at school level, supervising proper school-student, teacher-student, student-student, and parent student relationship. In addition, social workers can work on creating awareness about cultural opportunities of youth offending in the community level.

Once more, rehabilitating youth offenders in the institution of the correctional centers in providing psycho social treatment and working to reintegrate offenders with their family and community to create better future can be another area of social workers' contribution to prevent recidivism.

To make evidence based practice, social workers' role as a researcher can also be very important. It provides evidence for practice and enables to look further in to the awareness of the communities about the overall issue of youth offending distinctively from the adult offenders. In addition, conducting enquiries regarding youth offending can contribute to the scientific community at large to get better insight of the issue.

Moreover, through examining the existing youth policy and programs', social workers can make advocacy in insisting the government to give more attention for youths and work for the implementations of existing policy and programs. For example, in the study area they may work for the realization of programs associated with establishing youth centers in every community with its all intended functions.

Furthermore, in education, social workers should work to include youths' issue in the course more contextually, and identifying risk and protective factor simultaneously in addressing any youths' issue like that of positive development approach has to be more considered in the field of social work.

\section{Recommendations}

In order to address the problem of youth offending, the following recommendations are given 
to the responsible agent/s.

To the family: increased level of awareness, economic empowerment, and affiliated with normative behavior, proper parental supervision, family stability, socialization up on the positive behavior of the community, improved income of the family are factors mentioned to reduce youth's vulnerability to engage in crime.

Thus, the family members are responsibility to first creating stable family, maintaining their peaceful relationship, understand the youths' developmental changes and respond accordingly; create conducive environment for free communication; oversee their daily behavior, follow up external peer relationships where and with whom they interact, and controlling unconditional behavioral changes and deviation from the family and community's norm together with showing the fitting and clear standards of positive behaviors; empower this children economically as much as they can rather than letting them to be out of home without any support.

To the school and other stockholders: youths consistent enrolment in school, strict rules and supervision at school, providing several extra curricula activities, and delivering quality and creative education are mentioned to be the mechanism of the youth offending. Hence, school administrators and other stack holders should work for the provision of strict and constructive rules that facilitate students' engagement to education; follow up of students and teachers; create favorable school environment to attract students; acknowledge successful students to be modeled by other; and establish supportive extra curricula activities and encouraging students to participate based on their concern will be supportive to reduce the problem of youth offending.

In addition, coordination between school and family and other stockholders will be necessary; Woreda, zonal and regional educational bureau/ directives/ office to follow up the schools working situation, upgrade teachers and other school staff workers about academic and non academic issues to create competent individuals; and with the community as well good to solve immediate and consistent problems together.

Ultimately, ministry of education has to work for accessibility, reduce school dropout rate, and students' failure to pass regional and national exams through consistently monitoring policy limitation regarding delivering quality education. Strengthening curriculums which teach ethics and other positive behaviors could also be another concern.

To the community: several cultural risk factors of youth offending are identified. As a result create favorable conditions for youth like promote youths' participation and decisions making ability of the youth, controlling gun and alcohol consumptions, encouraging positively behaving youth while instructing the other one; and allocate resources to the youth like supporting the youth centers, youth associations or clubs organized for purpose which facilitate youths' creativity and participation in the community will better are possible protective factors of youth offending.

To the scientific community: as far as there is limitation of enquiries regarding youth offending, researchers are needed to provide inclusive survey research of youth offending, reoffending, and further intensive analytical researches on the risk and protective factors in rural urban and male female contexts to get full picture of the issue to design appropriate 
intervention mechanisms.

To NGOs: efforts have been made to trace NGOs working on youths, unfortunately, only a few in a few aspects mostly in health area are found at the time. Therefore, NGOs who need to engage are suggested to work in the study area to enhance the awareness level of the youth, the family and the community not only regarding crime but also in other problem behaviors as well. Moreover, they can engage on returnees from the correctional center to reintegrate to maintain their future life and prevent recidivism.

To Woreda, Zonal, Regional level officials: Economic problems, rural urban mobility and increment of street youth, high incidence of crime, cultural opportunities, availability and unlimited accessibility of alcohol, availability of guns and unending criminal attitudes towards the previous offenders were the main concerns mentioned to addressed.

Thus, police especially community policing department in collaboration with other stakeholders can work to increase the awareness of the community about crime and the cultural contexts of it such as revenge, and alcohol intensively. Children and youths at least up to a certain age have to be restricted not to use alcohol. Legal or illegal ownership of gun for youths as well must be controlled. Community policing department can use community's organizations such as religious institutions, idir and other helping organizations to better implement the change. Furthermore, in line with their activity, community policing officers could encourage traditional conflict resolution methods to be strong and recognized in the community.

Female, children, and youth affaire office should be strong and develop dynamic and contextual programs; facilitate to use existing youth centers and strive to make better in provision of services to get knowledge and skills; launch different youth clubs and initiate youths to participate with their interest including free services so that the community will have positive attitudes and create positive relationship with the youths.

To the court and police officials: Well educated, trained and experienced lawyers to prevent False and/or collective accusation are mentioned as an opportunity. Because they argued that it create further uncertainty not only among the offender and victim but also for the family as well. So regional, zonal and Woredal level court and police officials should work to improve crime investigation system scientifically and reduce false and/or collective accusation.

Officials from sport, police, small scale enterprise, training center such as TVT, and other NGOs would work in cooperation regarding youth's issue.

To the top policy and decision makers: False and/or collective accusation due to corruption and weak investigation system, poor administration of the correctional center, and less political commitment towards youths issue were mentioned as the problem that caused youths' offending behavior. Therefore, strong, accountable and committed government system to correct maladministration including corruption; and well organized and trained personnel of the police and lawyers to better detect crime and process the legal issue will be better. Moreover, looking the contemporary situation, and as the demographic composition, the government should give deserving attention to youth.

Federal agency of correctional center has to work to provide separate correctional center for the adult and the children below the age of 18. Apart from separating the center, improved 
rehabilitation services for each group should be given to reduce youth's recidivism.

Female, children and youth minister must work to establish youth centers with all possible and constructive departments comprehensively in every community; and the government could create the way the community themselves to take the responsibility to finance and follow up the progress of the youths and youth centers.

Key political decision makers should recognize the economic problem of the community. In collaboration with regional officials ways have to be provided how to get economic development in the community to reduce youth unemployment, mass migration towards urban areas, and easing street youths which are assumed to reduce the incidence of youth crime. Moreover, awareness creation in the community could be made and basic issues that causes for recurrent conflict (like boundary problems and other cultural factors) have to be addressed systematically.

Strong and all inclusive small scale and micro enterprise services should be provided for all groups; since there is scarcity of land in rural area, rather than distributing unused and communal lands to youths, it will be good solution if irrigation is expanded to increase productivity. Moreover, irrigation will enable youths to work with their family since it needs more human labor.

Youths who are unemployed, street youths, addicted and youths who have got mental and psychological illness and other more are becoming offenders. Thus, together with creating job opportunities and supplementary services, institutional based youth establishment centers have to be established and provide basic needs like foods with some sort of training for their further life would be very appropriate especially to the street and absent parent youths.

\section{References}

Abraham, G. (2010). an exploratory study on the experience of out-of-school youths in Arada Sub city, Addis Ababa city administration. A thesis conducted for the completion of MSW at Addis Ababa University, Ethiopia.

African Union. (2011). Status of the African youth report (report). Retrieved from http://africa-youth.org/sites/default/files/State $\% 20$ of $\% 20$ the $\% 20$ African $\% 20$ Youth $\% 20$ Report \%202011\%20\%28English\%29.pdf

Arizona Criminal Justice Commission. (2012). Arizona Youth Survey conducted. Arizona Youth Survey State Report.

Arizona Criminal Justice Commission. (2014). Arizona Youth Survey conducted. Arizona Youth Survey State Report.

Baxter, P., \& Jack, S. (2008). Qualitative Case Study Methodology: Study Design and Implementation for Novice Researchers. West Hamilton, Ontario, Canada: The Qualitative Report, 13(4), 544-559

Bohm, R. M., \& Haley, K. (2005). Introduction to Criminal Justice (2nd ed.). New York, USA: McGraw-hill.

Bronfenbrenner, U. (1979). The Ecology of Human Development. Cambridge, MA: Harvard University press.

Bronfenbrenner, U. (1989). Ecological system theory. In R. Vasta (Ed.), Six theories of child 
development: Revised Formulations and Current Issues. (Vol. 6, pp. 187-249). JAI Press, Greenwich, Connecticut.

Bronfenbrenner, U. (1989). Ecological systems theory. Annals of Child Development, 6, $187-24$

Bronfenbrenner, U. (1994). Ecological Model of human development. In International Encyclopedia of Education, Vol. 3, 2nd Ed. Oxford: Elsevier. Reprinted in: Gauvain, M. \& Cole, M (Eds.), Readings on the development of children, 2nd Ed. (1993, pp. 37-43). NY: Freeman.

Case, S., \& Haines, K. (2007). Offending by Young People: A Further Risk Factor Analysis. Centre for Criminology and Criminal Justice, University of Wales Swansea, U.K. Security Journal, 20, 96-110. https://doi.org/10.1057/palgrave.sj.8350031

Center on Early Adolescence. (2008). The Cost of Youth Problem Behaviors. Retrieved from https://www.earlyadolescence.org/cost date of retrival-12/15/14

Colton, D., \& Covert, R. W. (2007). Designing and Constructing Instruments for Social Research and Evaluation. San Francisco, USA: John Wiley \& Sons, inc.

Creswell, J. W. (2003). Research Design: Qualitative, Quantitative and Mixed Methods Approaches (2nd ed). Thousand Oaks, California, USA: SAGE publication.

Crow, I., \& Semmens, N. (2006). Researching Criminology. Maidenhead, Berkshire, England: Open University Press.

Curtain, R. (2003). Youth in extreme poverty: Dimensions and country responses. In World Youth Report: The Global Situation of Youth. New York: United Nations.

Date of retrieval, 18/12/20014.

Davies, D. (2011). Child development: A practitioner's Guide, third edition. On Social Work practice with Children and Families, Boyd, N. (Eds.). Guilford Press, New York, USA.

Dawson, C. (2007). A Practical Guide to Research Method: A User-Friendly Manual For Mastering Research Techniques And Projects (3rd ed.). Oxford, United Kingdom: How to content a division of How To Books Ltd.

Debre Marko's correctional administration. (2012, 2013, \& 2014). Annual report.

Debre Marko's city administration communication office. (2015). The green Debre Marko's bulletin prepared by Debre Marko's city administration communication office.

Dekovic, M. (1999). Risk and Protective Factors in the Development of Problem Behavior during Adolescence. Journal of Youth and Adolescence, 28(6), 667-685. https://doi.org/10.1023/A:1021635516758

East Gojjam Zone Economic development directive. (2015). Population size by sex and age group and urban rural distribution.

East Gojjam Zone police directive. (2015). Annual police record report.

East Gojjam Zone tourism directive. (2006). General information about East Gojjam zone.

Endalew, L. (2013). A Move towards Restorative Justice In Ethiopia: Accommodating Customary Dispute Resolution Mechanisms With The Criminal Justice System. Thesis Conducted For Master's Thesis in Peace and Conflict Transformation, University Of Tromsø: Norway. 
Farrington, D. P. (1986). Age and Crime. In M. Tonry, \& N. Morris (Eds), Crime and Justice: An Annual Review of Research, 7, 189-250. Oxford: Clarendon Press. https://doi.org/10.1086/449114

Farrington, D. P. (1995). Teenage anti-social behavior. In M. Rutter (Ed.), Psychosocial Disturbances in Young People. Challenges for Prevention. Cambridge: Cambridge University Press.

Farrington, D. P. (1995). The Twelfth Jack Tizard Memorial Lecture. The Development of Offending and Anti-social Behavior from Childhood: Key Findings from the Cambridge Study in Delinquent Development. Journal of Child Psychology and Psychiatry, 36(6), 929-964. https://doi.org/10.1111/j.1469-7610.1995.tb01342.x

Federal Democratic Republic of Ethiopia. (2004). The Criminal Code of the Federal Democratic Republic of Ethiopia, Proclamation No.414/2004. Addis Ababa, Ethiopia.

Fox, A. M. (2008). An Examination of Risk and Protective Factors, Drug Use, and Delinquency in Trinidad and Tobago. A Thesis Presented for the Partial Fulfillment of the Degree Masters Of Science, Arizona State University.

Geason, S., \& Wilson, P. R. (1988). Crime Prevention: Theory and Practice.Canberra, Australian:Australian Institute of Criminology.

Guan, X. (2012). Early Behavior Problems in School, Juvenile Delinquency, and Adult Incarceration: A Longitudinal Examination of Pathways to Crime among Ten-Year Birth Cohort in Louisiana. China: Yancheng Institute of Technology.

Hepworth, D. Rooney, R. Rooney, G. D, Gottfried, K. S., \& Larsen, A. (2010). Direct Social Work Practice Theory and Skills (8th Edition). Brooks/Cole, Cengage Learning, Canada.

Higgins, G. E. (2009). Quantitative versus Qualitative Methods: Understanding Why quantitative Methods are Predominant in Criminology and Criminal Justice. Journal of Theoretical and Philosophical Criminology, 1(1).

Hussein, A. (2009). The use of Triangulation in Social Sciences Research: Can qualitative and quantitative methods be combined? Journal of Comparative Social Work, 1, 1-12.

Hutchison, E. D. (1999). Dimensions of Human Behavior: Person and Environment. Thousand Oaks, California: Pine Forge Press.

IFSW and the IASSW. (2004). Ethics in Social Work, Statement of Principles" The document approved at the General Meetings of the in Adelaide, Australia.

Kemp, S. P. (2015). Ecological Framework. Oxford university press. Retrieved from http://www.oxfordbibliographies.com/view/document/obo-9780195389678/obo-9780195389 678-0095.xml

Kreuger, L., \& Newman, W. (2006). Social Work Research Methods: Qualitative and Quantitative approaches. Boston, MA, USA: Person Education, Inc.

Mack, N., Woodsong, C., MacQueen, K. M., Guest, G., \& Namey, E. (2005). Qualitative Research Methods: A Data collector's Field Guide. North Carolina, USA: Family health international

Matsueda, R. L. (2006). Differential Social Organization, Collective Action, and Crime. University of Washington, USA: Business Media B.V. 
McLeroy, K. R., Bibeau, D., Steckler, A., \& Glanz, K. (1988). An ecological perspective on health promotion programs. Health Education Quarterly, 15, 351-377. https://doi.org/10.1177/109019818801500401

Mcvie, S. (2009). Criminal Careers and Young People. A book chapter in Barry, M., \& McNeile (Eds.) Youth Offending and Youth Justice: Research Highlights in social work. London, England: Jessica Kingsley Publisher.

Moon, S. S., Patton, J., \& Rao, U. (2011). An Ecological Approach to Understanding Youth Violence: The Mediating Role of Substance Use. J Hum Behav Soc Environ, 20(7), 839-856. https://doi.org/10.1080/10911351003751918

Mortimer, R. (2010). Risk factors for offending: A developmental approach. A dissertation made for the degree of Doctorate in Forensic Psychology Practice (Foren Psy D), Centre for Forensic and Criminological Psychology, University of Birmingham.

NACCE (North American community for cultural ecology). (2015). Ecological theory of brenfrender. Retrived from http://nacce.org/ecological-theory-of-bronfenbrenner/ Date of retrival 15/08/2015

Natasha, M., Cynthia, W., Macqueen, K. M., Guest, G., \& Namey, E. (2011). Qualitative Research Methods: A Data collector's Field Guide. North Carolina, USA: Family Health International.

Neale, P., Thapa, S., \& Boyce, C. (2006). Preparing a Case Study: A Guide for Designing and Conducting a Case Study for Evaluation Input.Pathfinder International Tool Series to Monitoring and Evaluation

Neuman, W. L. (2007). Basics of Social Research: Qualitative and Quantitative Approaches. (2nd ed.). Madison, USA: Pearson Education, Inc.

Ozarow, L. (2011). An Exploratory Study of How Youth Offenders Perceive their Experience of Education. Master's thesis made in University of East London.

Pardeck, J. T. (2015). An Ecological Approach for Social Work Practice. The Journal of Sociology \& Social Welfare, 15, 132-143

Piko, B. F., Fitzpatrick, K. M., \& Wright, D. R. (2005). A risk and protective factors framework for understanding youth's externalizing problem behavior in two different cultural settings. European Child \& Adolescent Psychiatry, 14(2), 95-103. https://doi.org/10.1007/s00787-005-0437-z

Pogrebin, M. (Ed.). (2004a). A view of the offender's world: About criminals. Belmont, CA: Sage.

Pollard, J. A., Hawkins, D., \& Arthur, M. W. (1999). Risk and protective factors: Are both necessary to understand diverse behavioral outcomes in adolescence? Social Work Research, 23, 145-158. https://doi.org/10.1093/swr/23.3.145

Rutter, M. (1987). Psychosocial resilience and protective mechanisms. American Journal of Orthopsychiatry, 57, 316-331. https://doi.org/10.1111/j.1939-0025.1987.tb03541.x

Sampson, R. J, \& Laub, J. H. (1992). Crime and Deviance in the Life Course. Annual Review of sociology, 18, 63-84. https://doi.org/10.1146/annurev.so.18.080192.000431

Shaffer, C. S. (2014). Risk and Protective Factors for Youth Gang Involvement in Canada: An 


\section{Macrothink}

International Journal of Social Work

ISSN 2332-7278

2017, Vol. 4, No. 2

Ecological Systems Analysis. Thesis Conducted For The Partial Fulfillment Of The Degree Of Master of Arts In Psychology, Simon Fraser University, British Columbia, Canada.

Stake, R. (1995). The art of case research. Newbury Park, CA: Sage Publications.

Stokols, D., Lejano, R. P., \& Hipp, J. (2013). Enhancing the Resilience of Human-Environment Systems: A Social Ecological Perspective. School of Social Ecology, University of California, Irvine.

Stouthamer-Loeber, M., Loeber, R., Farrington, D. P., Zhang, Q., vanKammen, W., \& Maguin, E. (1993). The double edge of protective and risk factors for delinquency: Interrelations and developmental patterns. Development and Psychopathology, 5, 683-701. https://doi.org/10.1017/S0954579400006234

Teddlie, C., \& Yu, F. (2007). Mixed Methods Sampling: A Typology with Examples. Journal of Mixed Methods Research, 1, 77-99. https://doi.org/10.1177/2345678906292430

Sintayehu, T. (2017). Exploratory research on youth offending: Risk Factors Associated with Youth Offendingin East Gojjam Zone,Ethiopia. International Journal of Scientific \& Engineering Research, 8(7), 1364-1411.

UNDP Human Development Report Office. (2014). Youth Vulnerabilities in Life Course Transitions. Occasional Paper.

Vien, A. (2009). An Investigation In to the Risk and Protective Factors Associated with Youth Offending, A dissertation made for the requirement of Doctorate in Forensic Psychology Practice. The University of Birmingham.

Winch, P. (2012). Ecological models and multilevel interventions: Health Behavior Change at the Individual, Household and Community Levels. Public Lecture at Johns Hopkins Bloomberg School of Public Health.

Wolfgang, M. E., Savitz, L., \& Johnston, N. (1970). Sociology of crime and delinquency (2nd ed.). USA: John Wiley and sons inc. https://doi.org/10.1177/002242787000700210

Yin, R. K. (1989). Case Study Research: Design and Methods (2nd ed.). Newbury Park, CA: Sage Publications.

Yin, R. K. (2004). Case Study Methods (A revised draft). Washington, DC, USA: COSMOS Corporation.

Youth Justice Board. (2002). Corporate Plan 2002-03 to 2004-05And Business Plan 2002-03. Youth Justice Board. (2005). Risk and protective factors. Research undertaken by Communities that Care on behalf of The Youth Justice Board.

\section{Copyright Disclaimer}

Copyright reserved by the author(s).

This article is an open-access article distributed under the terms and conditions of the Creative Commons Attribution license (http://creativecommons.org/licenses/by/3.0/). 